\title{
The Effects of Nonperforming Loans on Dynamic Network Bank Performance
}

\author{
Day-Yang Liu, ${ }^{1}$ Ya-Chiang Wu, ${ }^{2}$ Cheng-Hsien Lin, ${ }^{3}$ and Wen-Min $\mathrm{Lu}^{3}$ \\ ${ }^{1}$ Graduate Institute of Finance, National Taiwan University of Science and Technology, No. 43, Sec. 4, Keelung Rd., Taipei 106, Taiwan \\ ${ }^{2}$ School of Management, National Taiwan University of Science and Technology, No. 43, Sec. 4, Keelung Rd., Taipei 106, Taiwan \\ ${ }^{3}$ Department of Financial Management, National Defense University, No. 70, Section 2, Zhongyang North Road, Beitou, \\ Taipei 112, Taiwan
}

Correspondence should be addressed to Wen-Min Lu; wenmin.lu@gmail.com

Received 26 January 2017; Revised 15 April 2017; Accepted 4 May 2017; Published 4 June 2017

Academic Editor: Alicia Cordero

Copyright (C) 2017 Day-Yang Liu et al. This is an open access article distributed under the Creative Commons Attribution License, which permits unrestricted use, distribution, and reproduction in any medium, provided the original work is properly cited.

\begin{abstract}
This paper is to explore the relationship between banks' performance and their nonperforming loans (NPLs). The banks' performance through a network production process structure with NPLs is developed. With increasing NPLs in recent years, the quality of lending assets is a key significant and influencing factor for banks' operational risk. The research methodology is to integrate the radial and nonradial measures of efficiency into the network production process framework with NPLs; this study utilizes network epsilon-based measure model to evaluate the banking industry performance. In addition, the key characteristics of the bank industry including those of financial holding companies and privatized government banks are needed to be figured out and to provide insight into what causes imperfectly competitive conditions for some banks. The results demonstrate that the banking sector grew consistently in three aspects of operation: operating performance, profitability performance, and risk management in the last five years of the subject period. These results showed that the overall banking sector was capable of pursuing growth in both operations and profits while accounting for risk management. The potential applications and strengths of network data envelopment analysis in assessing financial organizations are also highlighted.
\end{abstract}

\section{Introduction}

The purpose of this study is motivated by the developments in the literature on the relationship between banks' performance and financial stability and on the effort that is currently being made to improve nonperforming loans (NPLs) [1-3]. During the last decade, NPLs have been one of the most significant bank trends [4]. The World Bank indicated that when banks adopt NPLs as one of the performance indicators, their banks' performance improves greatly. Figure 1 shows that banking market had experienced quite significant high ratio of bank nonperforming loans to total gross loans (\%) in the range of $3-4 \%$ over the past 10 years period. Central Bank of the Republic of China (Taiwan) statistics and publications stated that NPLs ratio of Taiwan banks for the first quarter in 2004 fell from $2.81 \%$ to $0.25 \%$ in December 2014 which is the lowest in recent banking history. In general, banks reduce NPLs not only to enhance their operating performance and profitability performance [5] but also to let their risk management become better [6]. Banks have realized that NPLs not only enhance the image of corporations but also may create profits for them. When more banks implement NPLs, it becomes not only a popular trend but also an important part of the core competitiveness of banks. In summary, NPLs play a significant role in banks' performance, implying that NPLs are now seen as an integral part of strategy.

The early literature on bank efficiency has focused mainly on total productivity [7] and bank branch efficiency $[8,9]$. Recent studies have trended towards the relationship between bank efficiency and risk management [10-13]. The results in these articles demonstrate that the incorporation of financial risk variables (e.g., NPLs or risky assets) into the analysis of efficiency estimation and ranking is significant. Therefore, we investigate the impact of risk variables on bank performance. Thus, NPLs have been selected as risk variables and, for the purposes of this paper, are considered undesirable outputs. 


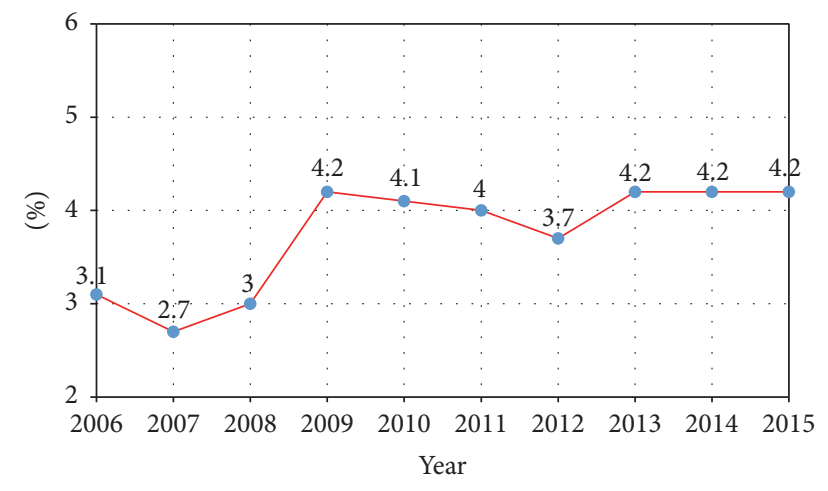

FIGURE 1: Bank nonperforming loans to total gross loans for global banks (data form World Bank).

Bank performance evaluation problems are inherently complex problems with multilayered internal linking activities and multiple entities. Data Envelopment Analysis (DEA) models [14, 15] have been used to evaluate the relative performance of banks by using multiple inputs and outputs at the same time. However, the conventional DEA models cannot take into consideration the complex nature of banks with internal linking activities (e.g., NPLs or risky assets). Network DEA models using radial or nonradial measures of efficiency are used for bank performance evaluation problems [16]. However, these models ignore problems where radial and nonradial inputs/outputs must be considered simultaneously. DEA models using epsilon-based measures (EBM) of efficiency are firstly proposed for a simultaneous consideration of radial and nonradial inputs/outputs [17].

The object of this report is to provide an alternative perspective and characterization of the performance to evaluate the operating efficiency of leading banking firms in Taiwan, which should provide additional managerial insights into the competitive advantage. The contributions of this study include (a) providing an alternative perspective and characterization measuring the banks' performance through a network production process structure including "operating stage," "profitability stage," and "risk management stage," by utilizing the NEBM model and stressing the importance of the growing strength and competitiveness; (b) applying the NEBM model [18] to investigate the radial and nonradial measures of efficiency into a unified framework for a bank performance evaluation problem; and (c) concerning whether differences exist in the various efficiency characteristics of the bank industry including those of financial holding companies (FHCs) and privatized government banks (PGBs).

Related prior studies that have influenced this study are discussed in Section 2. The design of the performance model and an introduction of the methodology are addressed in Section 3. The empirical results and interpretations are provided in Section 4. Finally, Section 5 concludes with the finding of this study.

\section{Literature Review}

The rapid growth of the Taiwan economy, particularly since 1991, has led a number of scholars, both within Taiwan and overseas, to study the performance of the Taiwan banking industry. However, these earlier studies have not taken NPLs into account, although NPLs are a critical component to impact the development of the Taiwan banking industry [19]. Later studies have included NPLs as a fixed input and measured banking efficiency which strongly evidence that NPLs are an important undesirable output $[1,6,20]$.

Many scholars have employed the directional distance function to measure banking efficiency with NPLs because of its ability to solve the oriented problem successfully [21,22]. Fukuyama and Weber [23] introduced that directional distance function solves the oriented problem, which employs a generalized nonradial and nonoriented data envelopment analysis to solve both problems. This model is described as the slack-based measurement directional distance function.

Chang et al. [24] and $\mathrm{Hu}$ et al. [25] found that the higher the ratio of government stockholding or the greater the scale of the commercial banks, the lower the ratio of NPLs. Subsequently, Li (2005), Park and Weber (2006), and Fukuyama and Weber (2008) also treat a bank's NPLs as undesirable outputs [26-28]. These studies demonstrated that the consideration of undesirable outputs has a great influence on measuring performance. Accordingly, this research incorporates the NPLs into the analysis of efficiency estimation and regards the NPLs as risk variables.

\section{Research Design}

3.1. A Network Production Process Structure with NPLs for Bank. A network production process structure with NPLs is designed to open the black box and explain internal operating structure for bank. The study indicates that the variables meet the criteria required to explore the operational efficiency of banks in the operating stage and their application of resources for maximum benefit. Research indicates that human, capital, and operating expenses represent the most important factors to explore. The bank's financial market operations require substantial manpower and play a key role in capital markets and financial capital flows. For good performance, banks must improve overall financial market performance.

Therefore, the "operating performance" measures the bank's management to generate competitive superiority, consisting of three types of its major costs (labor, fixed asset, and operational expenses) and three outputs (deposit, loans, and NPLs). The profitability stage examines profit performance, which represents output items (deposits and loans) from the operating stage as inputs to the profitability stage. The output items of the profitability stage are the interest earnings [29] and operating profit. The risk management consists of the input item that is the output of operating performance output item (NPLs) and two output items including nonaccrual loans and allowance for uncollectible accounts. The network production process structure with NPLs is shown in Figure 2 and the variables are as defined in Table 1.

3.2. Data Collection and Descriptive Statistics. The indicators of inputs and outputs are obtained from the Taiwan Economic Journal database. For the collection of NPLs and writtenoff bad debts, the financial institutions are required to have 


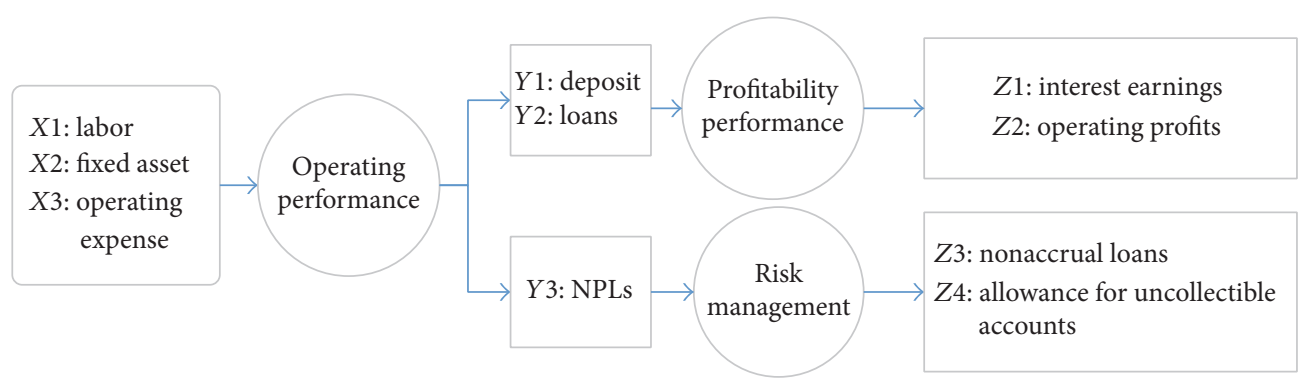

FIGURE 2: A network production process structure with NPLs for bank.

TABLE 1: Variable definitions.

\begin{tabular}{|c|c|c|}
\hline & Variables & Description \\
\hline \multirow{3}{*}{ Input $(X)$} & $X 1$ : labor & Productive activity, especially for the sake of economic gain \\
\hline & $X 2$ : fixed asset & $\begin{array}{l}\text { This item represents the difference between sale value and net book value } \\
\text { (including the amount of any revaluation of the assets previously included in } \\
\text { revaluation reserves) from the sale of fixed assets and/or investments }\end{array}$ \\
\hline & X3: operational expenses & $\begin{array}{l}\text { The total costs and expenses incurred for all divisions of the company deduct } \\
\text { component of labor and related expense }\end{array}$ \\
\hline \multirow{3}{*}{ Input/output $(Y)$} & $Y 1$ deposit & $\begin{array}{l}\text { It is a credit for the party who placed it, and it may be taken back (withdrawn), } \\
\text { transferred to some other party, or used for a purchase. It is often used with } \\
\text { respect to banks, where deposits are usually their main source of funding }\end{array}$ \\
\hline & Y2: loans & $\begin{array}{l}\text { In finance, a loan is the lending of money from one individual, organization, or } \\
\text { entity to another individual, organization, or entity }\end{array}$ \\
\hline & Y3: NPLs & $\begin{array}{l}\text { A loan is nonperforming when payments of interest and principal are past due by } \\
90 \text { days or more, or at least } 90 \text { days of interest payments have been capitalized, } \\
\text { refinanced, or delayed by agreement, or payments are less than } 90 \text { days overdue, } \\
\text { but there are other good reasons to doubt that payments will be made in full }\end{array}$ \\
\hline \multirow{4}{*}{ Output $(Z)$} & $Z 1$ : interest earnings & $\begin{array}{l}\text { Interest rate spread is the interest rate charged by banks on loans to private sector } \\
\text { customers minus the interest rate paid by commercial or similar banks for } \\
\text { demand, time, or savings deposits }\end{array}$ \\
\hline & $Z 2$ : operating profits & $\begin{array}{l}\text { Operating profit is the profit earned from a firm's normal core business } \\
\text { operations. This value does not include any profit earned from the firm's } \\
\text { investments (such as earnings from firms in which the company has partial } \\
\text { interest) and the effects of interest and taxes }\end{array}$ \\
\hline & $Z 3$ : nonaccrual loans & $\begin{array}{l}\text { All nonperforming loans shall be transferred to non-accrual loans account item } \\
\text { within six (6) months after the end of the payment period. However, those } \\
\text { restructured loans to be performed in accordance with the agreement shall not } \\
\text { be subject to this restriction }\end{array}$ \\
\hline & $\begin{array}{l}\text { Z4: allowance for } \\
\text { uncollectible accounts }\end{array}$ & $\begin{array}{l}\text { With regard to the write-off of nonperforming loans and nonaccrual loans, the } \\
\text { amount provided under the loan loss provision or the reserve against liability on } \\
\text { guarantees shall be used to offset [the write off], and, if such amount(s) is } \\
\text { insufficient, the deficiency shall be recognized as a loss in the current year }\end{array}$ \\
\hline
\end{tabular}

published the information in the annual report since the year 2004. Cooper et al. [30] suggested that the number of DMUs (Decision-Making Units) should be at least triple the number of inputs and outputs considered. In this study the number of banks is $286(26 \times 11)$, which is larger than triple the number of inputs and outputs, or $286>3(10)=30$.

To overcome the undesirable output, Seiford and Zhu (2002) [31] propose a way which deals with undesirable outputs in the DEA framework. Each undesirable output is multiplied by " -1 " and then finds a proper translation value $w$ to let negative undesirable output be positive. The translated bad output now ensured that the optimized undesirable output cannot be negative. This approach can truly reflect the real production process and is invariant to the data transformation within the DEA model. We therefore apply this method to treat the undesirable output factors in this study.

Finally, the importance and significance of input and output indicators indicate the relationship between the input and output indicators and their direction. We verify the correlation of input and output with the regression model to establish the adequacy of the variables in this study. The regression results are shown in Tables 2 and 3. The left column for the operating stage of this study shows the 
TABLE 2: Operating performance regression of input and output.

\begin{tabular}{lccc}
\hline $\begin{array}{l}\text { Operating stage } \\
\text { Inputs }\end{array}$ & \multicolumn{2}{c}{$\begin{array}{c}\text { Operating performance } \\
\text { Outputs }\end{array}$} \\
\hline Constant & Deposit & Loans & NPLs \\
Labor & -40318 & -28049 & 516 \\
Fixed asset & $114.5136^{* * *}$ & $94.5934^{* * *}$ & $1.9747^{* * *}$ \\
Operating expense & $0.0288^{* * *}$ & $0.0251^{* * *}$ & $0.0005^{* * *}$ \\
$R^{2}$ & $-0.0094^{*}$ & $-0.0133^{* *}$ & $-0.0009^{* * *}$ \\
Adjusted $R^{2}$ & 0.8085 & 0.7534 & 0.4033 \\
$F$ & 0.8065 & 0.7508 & 0.3969 \\
\hline
\end{tabular}

$* * *$ means are significantly different at $p<0.01 ; * *$ means are significantly different at $p<0.05$; means are significantly different at $p<0.1$.

TABLE 3: Profitability and risk management regression of input and output.

\begin{tabular}{|c|c|c|c|c|c|}
\hline \multirow{2}{*}{$\begin{array}{l}\text { Profitability stage } \\
\text { Inputs }\end{array}$} & \multicolumn{2}{|c|}{$\begin{array}{l}\text { Profitability performance } \\
\text { Outputs }\end{array}$} & \multirow{2}{*}{$\begin{array}{l}\text { Risk management stage } \\
\text { Inputs }\end{array}$} & \multicolumn{2}{|r|}{$\begin{array}{l}\text { Risk management } \\
\text { Outputs }\end{array}$} \\
\hline & Interest earnings & Operating profits & & Nonaccrual loans & Allowance for uncollectible accounts \\
\hline Constant & 705.6222 & 3581.7060 & Constant & 1018.1950 & 4149.9050 \\
\hline Deposit & $0.000856^{* * *}$ & $0.0033^{* * *}$ & NPLs & $0.8798^{* * *}$ & $0.3768^{* * *}$ \\
\hline Loans & $0.001112^{* *}$ & $0.0023^{*}$ & & & \\
\hline$R^{2}$ & 0.245549 & $0.2680^{*}$ & $R^{2}$ & 0.9167 & 0.2399 \\
\hline Adjusted $R^{2}$ & 0.240217 & 0.2628 & Adjusted & 0.9164 & 0.2373 \\
\hline$F$ & 46.05354 & 51.8058 & $F$ & 3126.5340 & 89.6538 \\
\hline
\end{tabular}

$* * *$ means are significantly different at $p<0.01 ; *$ means are significantly different at $p<0.05 ; *$ means are significantly different at $p<0.1$.

input indicators. According to the operating stage input indicator results, labor and fixed assets have a significant correlation indicating a high correlation between the inputs and outputs of operational efficiency in the operating stage of this study. The outputs of the operating stage are the inputs of the profitability stage. Additionally, the results show that deposits, loans, and NPLs have a significant correlation, which indicates that the variables chosen to disclose profitability and risk management are adequate. The research result validates the applicability and stability of the inputs and outputs of the research model and adequately represents profit performance and risk management.

3.3. Methodology: An Epsilon-Based Measure of Efficiency. In the present study, the NEBM model [18] is employed to construct assessment mechanisms for banks. The proposed method considered the diversity of inputs and outputs to determine the relative efficiency. The advantages of CharnesCooper-Rhodes model (1978) [14] and the slacks-based measure are combined to overcome the drawbacks of a conventional model that does not include efficiency measures in nonradial measures. Additionally, the problem concerning the concurrent and unidirectional increases or decreases of the conventional model inputs and outputs is addressed. The proposed method can improve all input-output variables, depending on the situation, without unidirectional variable increases or decreases to conform to practical applications and provide an accurate analysis.

Let us consider the bank structure. Each bank is represented as if it is a different bank for each of the successive years and an analysis of the $T \times n$ banks is performed by using NEBM models to obtain sharper and more realistic efficiency estimates. In this study, we treat each bank as a DMU. $x_{i j t}^{h}$, $y_{r j t}^{h}$, and $y_{v j t}^{h b}$ represent the $i$ th input $\left(i=1, \ldots, m_{h}\right)$, the $r$ th output $\left(r=1, \ldots, s_{h}\right)$, and the $v$ th undesirable output $(v=$ $\left.1, \ldots, q_{h}\right)$ of the $h$ th division $(h=1, \ldots, k)$ in the $j$ th bank $(j=1, \ldots, n)$ at time $t(t=1, \ldots, T)$, respectively. This study multiplies each undesirable output by “- 1 ” and then finds a proper translation value $w$ to let negative undesirable output be positive. The translated bad output now is $\bar{y}_{v j t}^{h}=y_{v j t}^{h b}+w$. $z_{j t}^{\left(h, h^{\prime}\right)}$ represents the intermediate measure between the $h$ th division and the $h^{\prime}$ th division of $j$ th bank at time $t(t=$ $1, \ldots, T)$. Consequently, $j$ th bank overall efficiency score of the NEBM model (1) is as follows:

$$
\begin{gathered}
\gamma_{j}^{*}=\min \quad \frac{1}{T} \sum_{t=1}^{T} \sum_{h=1}^{k} w_{h}\left(\theta_{j t}^{h}-\varepsilon_{x}^{h} \sum_{i=1}^{m_{h}} \frac{w_{i}^{h^{-}} s_{i t}^{h^{-}}}{x_{i o t}^{h}}\right), \\
\text { s.t. } \quad \sum_{t=1}^{T} \sum_{j=1}^{n} x_{i j t}^{h} \lambda_{j t}^{h}+s_{i t}^{h^{-}}=\theta_{j t}^{h} x_{i o t}^{h}, \\
i=1, \ldots, m_{h}, h=1, \ldots, k, \\
\sum_{t=1}^{T} \sum_{j=1}^{n} y_{r j t}^{h} \lambda_{j t}^{h} \geq y_{r o t}^{h}, \\
r=1, \ldots, s_{h}, h=1, \ldots, k,
\end{gathered}
$$




$$
\begin{aligned}
& \sum_{t=1}^{T} \sum_{j=1}^{n} \bar{y}_{v j t}^{h} \lambda_{j t}^{h} \geq \bar{y}_{v o t}^{h}, \\
& v=1, \ldots, q_{h}, h=1, \ldots, k, \\
& \sum_{t=1}^{T} \sum_{j=1}^{n} z_{j t}^{\left(h, h^{\prime}\right)} \lambda_{j t}^{h}=\sum_{t=1}^{T} \sum_{j=1}^{n} z_{j t}^{\left(h, h^{\prime}\right)} \lambda_{j t}^{h^{\prime}}, \\
& \sum_{t=1}^{T} \sum_{j=1}^{n} \lambda_{j t}=1, \\
& \theta_{j t}^{h} \leq 1, \\
& \quad j=1, \ldots, n, h=1, \ldots, k, t=1, \ldots, T, \\
& \lambda_{j t}^{h} \geq 0, \\
& j=1, \ldots, n, h=1, \ldots, k, t=1, \ldots, T, \\
& s_{i t}^{h^{-}} \geq 0, \\
& i=1, \ldots, m_{h}, h=1, \ldots, k, t=1, \ldots, T,
\end{aligned}
$$

where $w_{i}^{h^{-}}$is the weight of the ith input sent from the $h$ th division that satisfies $\sum_{i=1}^{m_{h}} w_{i}^{h^{-}}=1 . \varepsilon_{x}^{h}$ is determined based on the degree of the dispersion of the parameter associated with the inputs of the $h$ th division. $s_{i t}^{h^{-}}$represents the slack for the ith input in the $h$ th division at time $t . w_{i}^{h^{-}}$represents the weight of the $h$ th division for the $i$ th input slack and is determined by the decision makers. Constraints 1, 2, and 3 of Model (1) refer to the $h$ th division inputs, outputs, and undesirable outputs, respectively. The fourth constraint is related to the intermediate products where the right side represents the products sent from the $h$ th division and the left side shows the same products sent to the $h^{\prime}$ th division. Model (1) is called NEBM. The various steps on the NEBM DEA model proposed in this study are depicted.

Step 1. Form the diversity matrix of the $h$ th division. The diversity matrix is formed for the $h$ th division by using the $x_{i j t}^{h}$ values as follows:

$$
D^{h}=\left[D_{i, u}^{h}\right]_{m_{h} \times m_{h}}, \quad i, u=1, \ldots, m_{h} .
$$

In this matrix, $D_{i, u}^{h}$ represents the input vector dispersion ratio of $X_{i}^{h}=\left(x_{i, 1}^{h}, x_{i, 2}^{h}, \ldots, x_{i, n \times T}^{h}\right)$ compared with the input vector $X_{u}^{h}=\left(x_{u, 1}^{h}, x_{u, 2}^{h}, \ldots, x_{u, n \times T}^{h}\right)$.

$D_{i, u}^{h}$ is calculated as follows:

$$
\begin{aligned}
D_{i, u}^{h} & =D\left(X_{i}^{h}, X_{u}^{h}\right)=\frac{\sum_{j=1}^{(n \times T)}\left|c_{j}^{h}-c^{-h}\right|}{(n \times T)\left(c_{\max }^{h}-c_{\min }^{h}\right)}, \\
c_{j}^{h} & =\ln \frac{X_{i}^{h}}{X_{u}^{h}},
\end{aligned}
$$

$$
\begin{aligned}
c^{-h} & =\sum_{j=1}^{(n \times T)} \frac{c_{j}^{h}}{n}, \\
c_{\max }^{h} & =\max _{j}\left\{c_{j}^{h}\right\}, \\
c_{\min }^{h} & =\min _{j}\left\{c_{j}^{h}\right\} .
\end{aligned}
$$

Step 2. Form the affinity matrix of the $h$ th division.

After the diversity matrix is obtained, the affinity matrix for the $h$ th division is constructed as follows:

$$
S^{h}=\left[S_{i, u}^{h}\right]_{m_{h} \times m_{h}}, \quad i, u=1, \ldots, m_{h},
$$

where $S_{i, u}^{h}$ represents the degree of the affinity of input vector $X_{i}^{h}$ to $X_{u}^{h}$. $S_{i, u}^{h}$ is calculated by using the following equation:

$$
S_{i, u}^{h}=1-2 D_{i, u}^{h} \text {. }
$$

Step 3. Calculate $\varepsilon_{x}^{h}$ and $w_{i}^{h^{-}}$from the affinity matrix.

After $S^{h}$ matrix is obtained, the biggest eigenvalue of $\rho_{x}^{h}$ and its corresponding vector $w_{x}^{h}=\left(w_{1, x}^{h}, w_{2, x}^{h}, \ldots, w_{m_{h}, x}^{h}\right)$ is calculated and the values of $\varepsilon_{x}^{h}$ and $w_{i}^{h^{-}}$are estimated by using the following equations:

$$
\begin{aligned}
\varepsilon_{x}^{h} & =\frac{m_{h}-\rho_{x}^{h}}{m_{h}-1} \quad\left(\text { if } m_{h}>1\right), \\
\varepsilon_{x}^{h} & =0 \quad\left(\text { if } m_{h}=1\right), \\
w_{i}^{h^{-}} & =\frac{w_{i x}^{h}}{\sum_{i x}^{m_{h}} w_{i x}^{h}} .
\end{aligned}
$$

When an input vector is compared with other vectors, the higher the degree of affinity is, the higher the value of $w_{i x}^{h}$ is as a part of that vector. Equation (7) confirms this premise.

\section{Step 4. Solve the NEBM model.}

After determining $\varepsilon_{x}^{h}$ and $w_{i}^{h^{-}}$, the NEBM model is used.

The $j$ th bank efficiency score of the $h$ th division at time $t$ is defined as follows:

$$
\gamma_{j t}^{h *}=\theta_{j t}^{h}-\varepsilon_{x}^{h} \sum_{i=1}^{m_{h}} \frac{w_{i}^{h^{-}} s_{i t}^{h^{-}}}{x_{i o t}^{h}},
$$

A bank is NEBM efficient provided that $\gamma_{j t}^{h *}$ equals 1 and $\mathrm{A}$ division is NEBM efficient at time $t$ provided that $\sum_{j=1}^{n} \gamma_{j t}^{h *}=$ 1 equals 1 at time $t$. Note that a bank does not become NEBM efficient unless all of its divisions are efficient.

\section{Empirical Results}

4.1. Estimation of Efficiency Scores. For the efficiency scores of the sample over the period 2004-2014, first of all, we must get $\varepsilon_{x}^{h}$ and $w_{i}^{h^{-}}$needs to be determined by established 
TABLE 4: Operating performance diversity matrix.

\begin{tabular}{lccc}
\hline & Deposit & Loans & NPLs \\
\hline Deposit & 0 & 0.0461 & 0.1418 \\
Loans & 0.0461 & 0 & 0.1492 \\
NPLs & 0.1418 & 0.1492 & 0 \\
\hline
\end{tabular}

TABLE 5: Operating performance affinity matrix.

\begin{tabular}{lccc}
\hline & Deposit & Loans & NPLs \\
\hline Deposit & 1 & 0.9077 & 0.7162 \\
Loans & 0.9077 & 1 & 0.7014 \\
NPLs & 0.7162 & 0.7014 & 1 \\
\hline
\end{tabular}

TABLE 6: Profitability performance diversity matrix.

\begin{tabular}{lcc}
\hline & Interest earnings & Operating profits \\
\hline Interest earnings & 0 & 0.1163 \\
Operating profits & 0.1163 & 0 \\
\hline
\end{tabular}

approximate variance matrix. We would like to determine them from the data set $(X, Y)$, since DEA is a data driven method. These two parameters are obtained from the newly defined affinity index between inputs or outputs. Thus, EBM takes into account diversity of input/output data and their relative importance for measuring technical efficiency. Then we introduce an affinity index between two vectors which replaces Pearson's correlation coefficient [17]. First, after the raw data in (3) obtain a diversity matrix, (4) obtains an affinity matrix, and the differences in operational efficiency, profitability, and efficiency of risk management are calculated in an affinity matrix. Tables 4 and 5 show the diversity matrix and the affinity matrix in operating performance. The maximum eigenvalue and eigenvector can be determined by the affinity matrix, and the calculation process is as follows:

$$
\begin{aligned}
\rho_{x} & =2.624, \\
w_{x} & =(0.344,0.342,0.313) .
\end{aligned}
$$

Hence we have

$$
\begin{aligned}
\varepsilon_{x} & =\frac{\left(m-\rho_{x}\right)}{(m-1)}=0.222 \\
w_{1}^{-} & =0.344, \\
w_{2}^{-} & =0.342, \\
w_{1}^{-} & =0.313 .
\end{aligned}
$$

Tables 6 and 7 show the diversity matrix and the affinity matrix in profitability performance. The maximum eigenvalue and eigenvector can be determined by the affinity matrix, and the calculation process is as follows:

$$
\begin{aligned}
\rho_{x} & =1.767, \\
w_{x} & =(0.5,0.5) .
\end{aligned}
$$

TABLE 7: Profitability performance affinity matrix.

\begin{tabular}{lcc}
\hline & Interest earnings & Operating profits \\
\hline Interest earnings & 1 & 0.7672 \\
Operating profits & 0.7672 & 1 \\
\hline
\end{tabular}

TABLE 8: Risk management diversity matrix.

\begin{tabular}{lcc}
\hline & Nonaccrual loans & $\begin{array}{c}\text { Allowance for } \\
\text { uncollectible } \\
\text { accounts }\end{array}$ \\
\hline $\begin{array}{l}\text { Nonaccrual loans } \\
\begin{array}{l}\text { Allowance for } \\
\text { uncollectible accounts }\end{array}\end{array}$ & 0.1031 & 0.1031 \\
\hline
\end{tabular}

TABLE 9: Risk management affinity matrix.

\begin{tabular}{lcc}
\hline & Nonaccrual loans & $\begin{array}{c}\text { Allowance for } \\
\text { uncollectible } \\
\text { accounts }\end{array}$ \\
\hline $\begin{array}{l}\text { Nonaccrual loans } \\
\text { Allowance for } \\
\text { uncollectible accounts }\end{array}$ & 0.7938 & 0.7938 \\
\hline
\end{tabular}

Hence we have

$$
\begin{aligned}
\varepsilon_{x} & =\frac{\left(m-\rho_{x}\right)}{(m-1)}=0.232 \\
w_{1}^{-} & =0.5, \\
w_{2}^{-} & =0.5 .
\end{aligned}
$$

Tables 8 and 9 show the diversity matrix and the affinity matrix in risk management. The maximum eigenvalue and eigenvector can be determined by the affinity matrix, and the calculation process is as follows:

$$
\begin{aligned}
\rho_{x} & =1.794, \\
w_{x} & =(0.5,0.5) .
\end{aligned}
$$

Hence we have

$$
\begin{aligned}
\varepsilon_{x} & =\frac{\left(m-\rho_{x}\right)}{(m-1)}=0.206 \\
w_{1}^{-} & =0.5, \\
w_{2}^{-} & =0.5 .
\end{aligned}
$$

Table 10 presents the results of operating performance, profit performance, and risk management over the period 2010-2014. Figure 3 shows a mild recession in banks' performances in the 2004-2007 period, followed by a transition in the overall banking sector in the 2008-2011 period, which was marked by a significant improvement in operating performances. Banks' performances plateaued in the 2012-2014 period, while maintaining good drivers of growth. The Asian Financial Crisis occurred in 1997, but it was not until 2000 
TABLE 10: Efficiency score.

\begin{tabular}{|c|c|c|c|c|c|c|c|c|c|c|c|c|}
\hline \multicolumn{13}{|c|}{ Operating performance } \\
\hline & 2004 & 2005 & 2006 & 2007 & 2008 & 2009 & 2010 & 2011 & 2012 & 2013 & 2014 & Total \\
\hline Mean & 0.810 & 0.806 & 0.801 & 0.795 & 0.826 & 0.870 & 0.902 & 0.916 & 0.922 & 0.926 & 0.933 & 0.864 \\
\hline SD & 0.086 & 0.074 & 0.082 & 0.093 & 0.083 & 0.083 & 0.076 & 0.076 & 0.067 & 0.062 & 0.067 & 0.095 \\
\hline \multicolumn{13}{|c|}{ Profitability performance } \\
\hline & 2004 & 2005 & 2006 & 2007 & 2008 & 2009 & 2010 & 2011 & 2012 & 2013 & 2014 & Total \\
\hline Mean & 0.496 & 0.494 & 0.581 & 0.607 & 0.527 & 0.430 & 0.347 & 0.403 & 0.449 & 0.462 & 0.510 & 0.482 \\
\hline $\mathrm{SD}$ & 0.269 & 0.210 & 0.201 & 0.188 & 0.180 & 0.170 & 0.175 & 0.144 & 0.121 & 0.155 & 0.184 & 0.199 \\
\hline \multicolumn{13}{|c|}{ Risk management } \\
\hline & 2004 & 2005 & 2006 & 2007 & 2008 & 2009 & 2010 & 2011 & 2012 & 2013 & 2014 & Total \\
\hline Mean & 0.536 & 0.580 & 0.642 & 0.636 & 0.642 & 0.628 & 0.672 & 0.767 & 0.782 & 0.796 & 0.859 & 0.686 \\
\hline $\mathrm{SD}$ & 0.155 & 0.158 & 0.145 & 0.145 & 0.140 & 0.154 & 0.168 & 0.129 & 0.149 & 0.156 & 0.122 & 0.177 \\
\hline
\end{tabular}

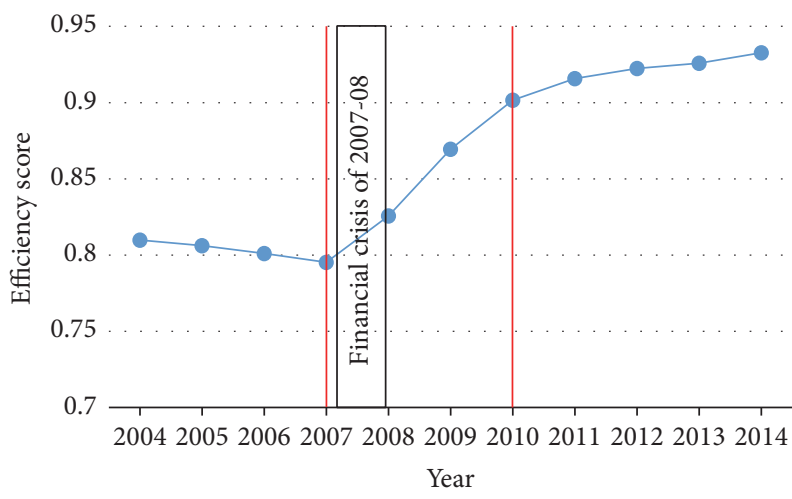

FIGURE 3: Trends in banks' performances in the operating stage.

that banks started to accumulate more bad debts and an increased ratio of NPLs, resulting from the difficult business environment and a drop in property prices. The Taiwanese government implemented financial reforms, which successfully addressed the further deterioration of bad loans. A bank exit mechanism was established, and the merger and acquisition of banks was legalized. The quality of personal consumer finance credit in the banking sector has worsened since 2005; the outbreak of the dual-card crisis (cash card and credit card) forced banks focusing on this area of business to tackle a large quantity of bad debts.

It is noted that in 2004-2007, with the effect of worsening business and personal finances, banks became more conservative in credit approvals. Further, financial regulations restricted the development of certain types of business transactions, resulting in a fall in the operating efficiency of banks, which dropped to its lowest point of 0.795 in 2007. In 2008, the overall operating performance of the banking sector slowly recovered from the recession, and its performance value improved to 0.826 , the highest when compared with that of the past five years, marking a key turning point. This improved performance value indicates that bank deposits were improving, and simultaneously, NPLs were under effective control. Banks maintained strong growth in their operating performance for the next three years, which can be observed from the massive annual growth in the performance value. The vibrant property market in Taiwan stimulated the growth of mortgage businesses, one of the reasons for the increase in performance value. The increase in cross-strait trade due to various investment protection acts and memorandum was another explanatory factor.

The stock market in 2008-2009 was impacted by the bankruptcy of Lehman Brothers, the Taiwan Capitalization Weighted Stock Index (TAIEX) repeatedly recorded relatively lowest points, and it became much more difficult for businesses to raise capital (i.e., Initial Public Offer IPO and Secondary Public Offering SPO) directly from the capital markets. If businesses had to increase their investments or maintain capital for operations, they would certainly turn to their banks and apply to increases in their credit limits. This situation contributed to continuous growth in the overall banking sector's operating performance over the next few years. Beginning in 2008, the Taiwanese banking sector set up leasing companies and Offshore Banking Unit (OBU), establishing branches or subsidiaries in Mainland China. Banks were eager to expand their business with Taiwanese companies and state-owned enterprises in Mainland China, and also in the interbank market, with the goal of extending their lending business from Taiwan to Mainland China. The operating performance of the overall banking sector remained at 0.92 or above during the 2012-2014 period, which was higher than each of the annual figures in the 2004-2011 period, clearly illustrating the input-output view.

Although both the productivity of bank deposits and loans and the quality of credit reached a high performance level, the drivers of growth slowed down. There was an urgent need to open up financial policy to find new drivers of growth. To attain fairness in gains and distributive justice, the Taiwanese government reintroduced the capital gains tax on securities transactions in 2012. Investors scurried to transfer their capital abroad, looking for better investment channels. These actions affected capital's driver and mobility in the stock market; businesses' desire to invest was suppressed; and the overall banking sector was affected adversely, making the expansion of deposit and loan businesses even more challenging. The overall banking sector was facing a plateau 


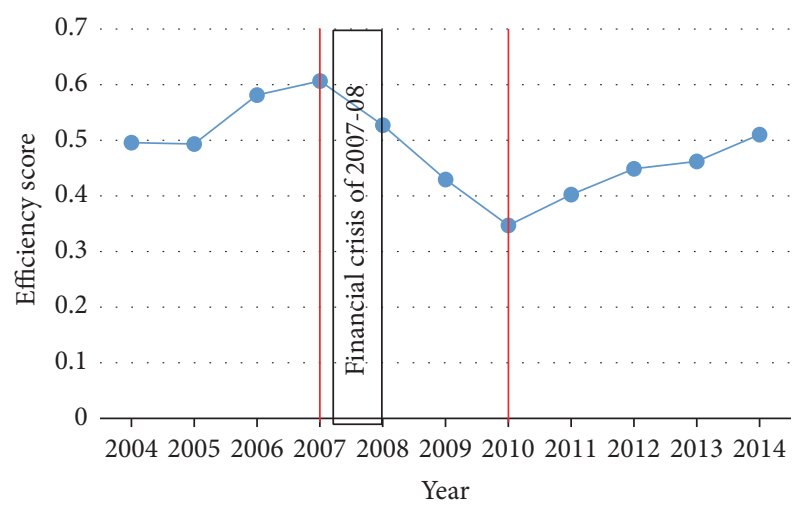

FIGURE 4: Trends of banks' performance in the profitability stage.

period in its operations, and to find ways to break through the limits on growth, banks could adopt merger and acquisition strategies to expand the scale of their operations, engage in financial operations and transactions, or introduce derivative products to investors that would generate income from handling charges.

Figure 4 analyzes banks' profitability performance in the profitability stage, revealing significant improvement in the 2004-2007 period. While there was a decline in performance of the overall banking sector in 2008-2010, performance improved slowly in the 2011-2014 period. After the Asian Financial Crisis, the Taiwanese government carried out its first financial reform, the banking sector allocated costs for the allowance of bad debts and writing off bad debts after 3-4 years, and banks adjusted their financial health and put an emphasis on risk management. The profitability performance of bank operations gradually recovered and reached a relatively satisfactory level; until the outbreak of the global subprime mortgage crisis in 2007, the performance metric was at 0.607. Beginning in 2008, Taiwanese banks were impacted by the global subprime mortgage crisis for 3 consecutive years, and there was a significant recession in the profitability performances of the banking sector.

The worst performance metric recorded was 0.347 in 2010. Even though there was a significant recession in the profitability performance of the banking sector during this period, compared with the operating performances in the operating stage, in 2008, the banking sector was leaving the trajectory of recession, and the drivers of operating performance growth remained strong for the subsequent three years. This proved that, during the global subprime mortgage crisis, banks' loan and credit quality remained relatively healthy and bad debts were controlled effectively. After the global subprime mortgage crisis, the profitability performances of the overall banking sector began to bounce back in 2011, reaching its plateau in 2014 with a performance metric of 0.510 . The banking sector's operating performance and profitability performance improved in this period, showing that banks' operations were getting more stable; banks were able to perform risk management and management while pursuing revenue and making profits.

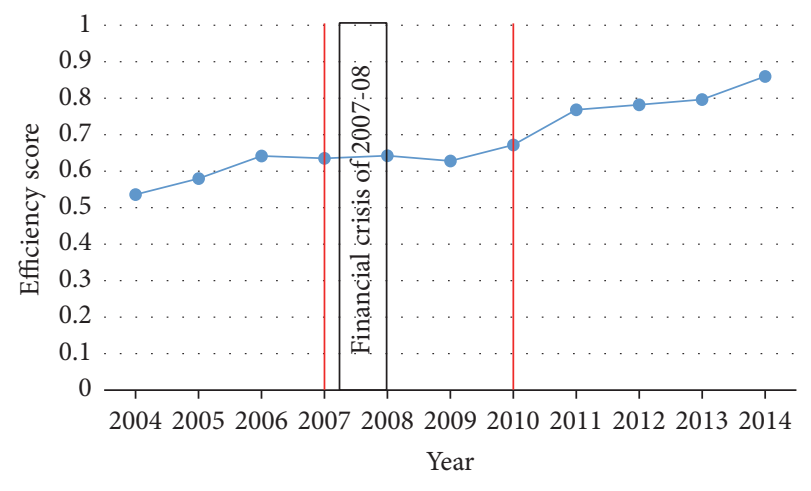

FIGURE 5: Trends of banks' performance in the risk management stage.

Figure 5 reveals that the risk management of the banking sector improved gradually from 2004 to 2006; the risk management of the banking sector was kept at a satisfactory level between 2007 and 2009, and risk management rose further between 2010 and 2014. In the 11-year risk management monitoring, with the exception of slight declines of the metric in 2007 and 2009, the risk management of the banking sector improved continuously, and the metric increased considerably from 0.536 in 2004 to 0.859 in 2014 .

The decline in the risk management metric in 2007 was due to the impact of the dual-card crisis of personal consumer finance (i.e., cash card and credit card), while the metric was affected by the global subprime mortgage crisis in 2009. Nonetheless, the risk management of the overall banking sector quickly returned to the trajectory of a growing trend after the occurrence of these two events, indicating that the banking industry had greatly improved its ability to adapt to changes in the external business environment. Simultaneously, the risk management of the banking sector experienced significant improvements and enhancements with the Basel Accords and the requirement of a capital adequacy ratio (Bank of International Settlement Ratio (BIS Ratio)), as stipulated by the monitoring authorities.

Generally, the study found that, in the last five years of the subject period, the banking sector grew consistently in three aspects of operation: operating performance, profitability performance, and risk management. These results showed that the overall banking sector was capable of pursuing growth in both operations and profits while accounting for risk management.

4.2. Characteristics and Performance of Banks within a Commerce Group. To explore whether differences exist in the various efficiency characteristics of the bank industry including those of FHCs and PGBs, a nonparametric statistical analysis, the Kruskal-Wallis Test, is used for unknown distribution scores [32]. The nonparametric statistical analysis results are presented in Table 11. However, an efficiency and value analysis cannot fully identify what key resource allocations the banks should review. Therefore, this section applies the NEBM model through further analysis of the use of bank resources. The differences in resource use indicate which 


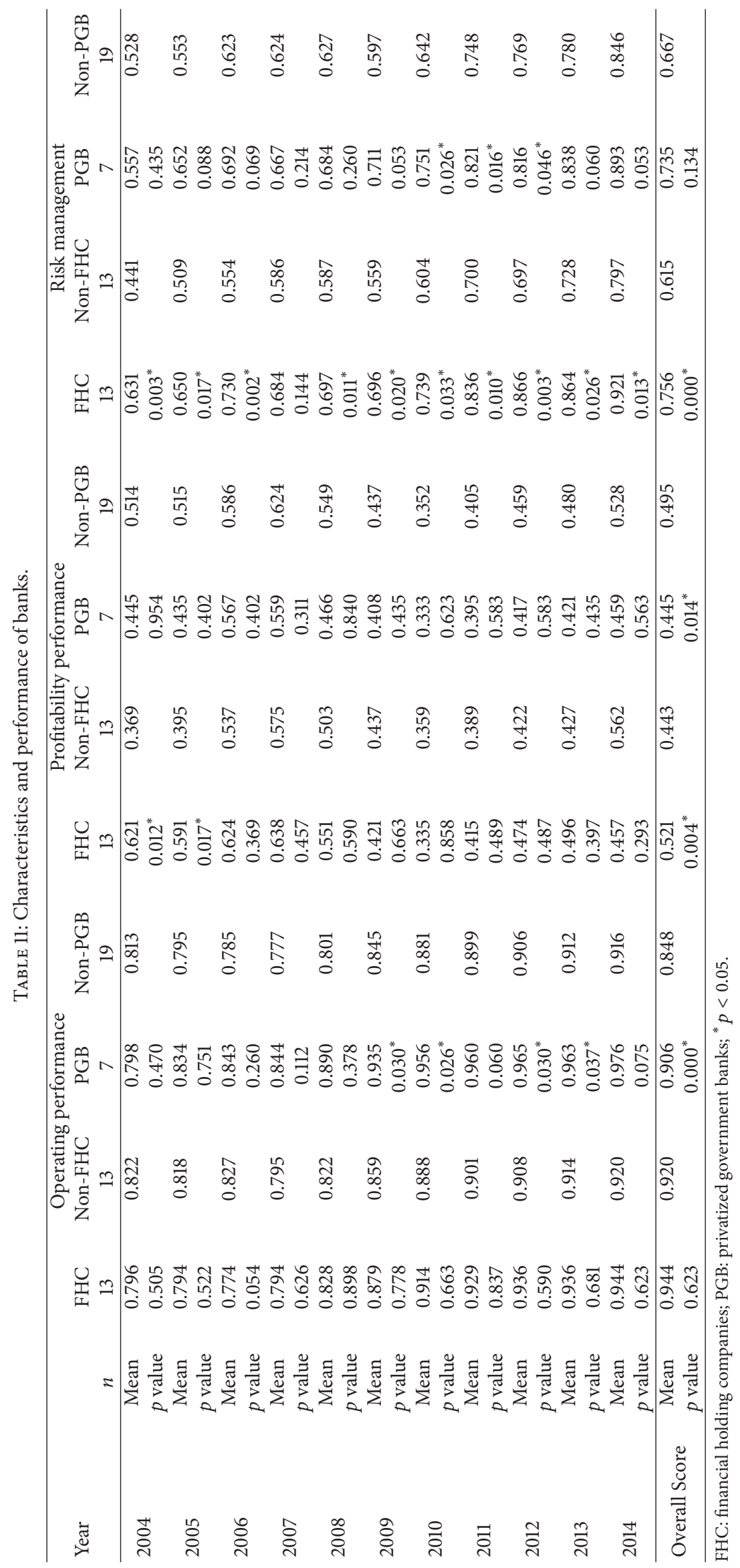


resources should be increased or decreased depending on the shortfalls in the bank item analysis and provide improved orientation.

Table 11 shows the analysis of the efficiency of banking institutions based on overall average efficiency scores, operational efficiency annual growth, progress in operating expenses, and manpower limitations. Banking institutions can exploit existing resources to obtain good performance and annual growth. FHCs show no significant growth, but PGBs show significant growth. In terms of profitability performance, efficiency is not as expected. Earnings failed to meet expectations and interest rate environment resulted in poor generated profit performance in the profitability stage. The average overall efficiency failed to grow year by year.

The FHCs' inefficiency value in terms of the effectiveness of risk management, profit, or outstanding performance compared to NFHCs and the efficiency of the value of government shares in banks and nongovernment bank shares good performance. This result shows that larger banks' performed better in adjusting the allocation of resources. These results showed that the overall banking sector was capable of pursuing growth in both operations and profits while accounting for risk management. The potential applications and strengths of network data envelopment analysis in assessing financial organizations are also highlighted.

\section{Concluding Remarks}

The study found that NPLs constituted one of the most influential factors affecting banks' performances; thus, the epsilon-based Internet data envelopment analysis was introduced into the study to explore banks' operations, profit making, and risk management, resulting in the following findings.

First, banks that fell under the framework of financial control performed better than other banks and had performance metrics in profit making and risk management that were affected significantly. This finding indicated that banks with a larger scale had better resource allocation than independent banks; risks were dispersed because of their synergy and diversification.

When the proportion of bad debts and NPLs among bank loans rose, if the government implemented financial reform, establishing a bank exit mechanism and legalizing mergers and acquisitions among banks, the loan problem could be controlled and prevented from worsening, and the emergence of systematic financial risk could be avoided. The requirements of the Bank of International Settlements-Basel Accords and the domestic monitoring authorities regarding the capital adequacy ratio (Bank of International Settlement Ratio (BIS Ratio)) have significantly improved and enhanced the risk management of the banking sector.

Second, the study built a risk assessment model of banks' bad debts, and then the network epsilon-based dynamic DEA method was used to conduct empirical analyses. The results demonstrated that our model could effectively explain the efficiency assessment of banks under the framework of risk management of bad debts. In the study of banks' operating efficacy in the operating stage, the model demonstrated that when banks were impacted by the external environment or events (such as the outbreak of the Asian Financial Crisis and the US subprime mortgage crisis in the studied period), a period of operational reorganization and financial health adjustment occurred, after which banks could again exhibit drivers of growth and efficacy. Furthermore, after comparing analyses of banks' profitability performances in the profitability stage to the results from the operating stage, it was found that banks' profitability performances and their operating efficacy are not necessarily consistent, indicating that the traditional profitability model of earning the difference between deposits and loans was becoming less important to banks, while the role of banks' investments, wealth management, and other financial products and services had increased. The model's subsequent analyses of the risk management stage revealed that risk management among banks continued to rise significantly, and there was a fiveyear period during which banks' improved operating efficacy and risk management were reflected in their profitability performance.

Third, the study found that in time banks' operating performances would enter a highly mature period of stability. If banks wish to increase their profitability and competitiveness, they must proactively develop diverse financial products and innovative financial services, expanding their operating scale and scope. In cases where the design of financial products and services, such as introducing and selling Target Redemption Forward products, crosses the professional border of banking, the introduction of commodities' securitization and futures option leverage would prompt banks to face enormous challenges. The government is unable to preemptively monitor, detect, and regulate the overall risk to the banking sector. When an incident deteriorates, it can easily trigger systematic risks, and a financial crisis can emerge more easily than in the past. The risk assessment model of bad debts in this study demonstrated that the inclusion of innovative financial businesses could more effectively prevent banks' risks becoming uncontrollable, as well as reflecting banks' performance assessment accurately.

\section{Additional Points}

Highlights. (i) The quality of lending assets is a key significant and influencing factor for banks' operational risk. (ii) This paper is to explore the relationship between bank performance and their nonperforming loans (NPLs). (iii) To integrate the radial and nonradial measures of efficiency into the network production process framework with NPLs, this study utilizes network epsilon-based measure model to evaluate the banking industry performance. (iv) The results demonstrate that the banking sector grew consistently in three aspects of operation: operating performance, profitability performance, and risk management in the last five years of the subject period.

\section{Conflicts of Interest}

The authors declare that they have no conflicts of interest. 


\section{References}

[1] N. Zhu, B. Wang, Z. Q. Yu, and Y. R. Wu, “Technical Efficiency Measurement Incorporating Risk Preferences: an Empirical Analysis of Chinese Commercial Banks," Emerging Markets Finance and Trade, vol. 52, no. 3, pp. 610-624, March 2016.

[2] D. Y. Zhang, J. Cai, D. G. Dickinson, and A. M. Kutan, "Nonperforming loans, moral hazard and regulation of the Chinese commercial banking system," Journal of Banking and Finance, vol. 63, pp. 48-60, February 2016.

[3] Y. Zha, N. N. Liang, M. G. Wu, and Y. W. Bian, "Efficiency evaluation of banks in China: a dynamic two-stage slacks-based measure approach," Omega-International Journal of Management Science, vol. 60, pp. 60-72, April 2016.

[4] N. Zhu, B. Wang, and Y. R. Wu, "Productivity, efficiency, and non-performing loans in the Chinese banking industry," Social Science Journal, vol. 52, no. 4, pp. 468-480, December 2015.

[5] T. Hu and C. Xie, "Competition, Innovation, Risk-Taking, and Profitability in the Chinese Banking Sector: An Empirical Analysis Based on Structural Equation Modeling," Discrete Dynamics in Nature and Society, vol. 2016, no. article 3695379, 10 pages, 2016.

[6] H.-H. Liu and M. Cortes, "An assessment of the efficiency of operational risk management in Taiwan's banking industry: An application of the stochastic frontier approach," Journal of Operational Risk, vol. 10, no. 1, pp. 127-156, 2015.

[7] H. Fukuyama, R. Guerra, and W. L. Weber, "Efficiency and ownership: Evidence from japanese credit cooperatives," Journal of Economics and Business, vol. 51, no. 6, pp. 473-487, 1999.

[8] J. C. Paradi and H. Zhu, "A survey on bank branch efficiency and performance research with data envelopment analysis," Omega (United Kingdom), vol. 41, no. 1, pp. 61-79, 2013.

[9] J. C. Paradi, S. Rouatt, and H. Zhu, "Two-stage evaluation of bank branch efficiency using data envelopment analysis," Omega, vol. 39, no. 1, pp. 99-109, 2011.

[10] B. Maggi and M. Guida, "Modelling non-performing loans probability in the commercial banking system: Efficiency and effectiveness related to credit risk in Italy," Empirical Economics, vol. 41, no. 2, pp. 269-291, 2011.

[11] K. Matthews, "Risk management and managerial efficiency in Chinese banks: A network DEA framework," Omega (United Kingdom), vol. 41, no. 2, pp. 207-215, 2013.

[12] A. Ataullah, T. Cockerill, and H. Le, "Financial liberalization and bank efficiency: A comparative analysis of India and Pakistan," Applied Economics, vol. 36, no. 17, pp. 1915-1924, 2004.

[13] C. Girardone, P. Molyneux, and E. P. Gardener, "Analysing the determinants of bank efficiency: the case of Italian banks," Applied Economics, vol. 36, no. 3, pp. 215-227, 2004.

[14] A. Charnes, W. W. Cooper, and E. Rhodes, "Measuring the efficiency of decision making units," European Journal of Operational Research, vol. 2, no. 6, pp. 429-444, 1978.

[15] J. S. Liu, L. Y. Lu, and W. Lu, "Research fronts in data envelopment analysis," in Omega-International Journal of Management Science, vol. 58, pp. 33-45, January 2016.

[16] N. K. Avkiran, "An illustration of dynamic network DEA in commercial banking including robustness tests," Omega, vol. 55, pp. 141-150, 2015.

[17] K. Tone and M. Tsutsui, "An epsilon-based measure of efficiency in DEA - a third pole of technical efficiency," European Journal of Operational Research, vol. 207, no. 3, pp. 1554-1563, 2010.
[18] M. Tavana, H. Mirzagoltabar, S. M. Mirhedayatian, R. F. Saen, and M. Azadi, "A new network epsilon-based DEA model for supply chain performance evaluation," Computers \& Industrial Engineering, vol. 66, no. 2, pp. 501-513, October 2013.

[19] C. Kao and S.-T. Liu, "Stochastic data envelopment analysis in measuring the efficiency of Taiwan commercial banks," European Journal of Operational Research, vol. 196, no. 1, pp. 312-322, 2009.

[20] P. Guarda, A. Rouabah, and M. Vardanyan, "Identifying bank outputs and inputs with a directional technology distance function," Journal of Productivity Analysis, vol. 40, no. 2, pp. 185195,2013

[21] R. D. Banker, H. Chang, and S.-Y. Lee, "Differential impact of Korean banking system reforms on bank productivity," Journal of Banking and Finance, vol. 34, no. 7, pp. 1450-1460, 2010.

[22] M. Epure and E. Lafuente, "Monitoring bank performance in the presence of risk," Journal of Productivity Analysis, vol. 44, no. 3, pp. 265-281, 2015.

[23] H. Fukuyama and W. L. Weber, "A directional slacks-based measure of technical inefficiency," Socio-Economic Planning Sciences, vol. 43, no. 4, pp. 274-287, 2009.

[24] K. C. Chang, C. L. Lin, Y. Cao, and C. F. Lu, "Evaluating branch efficiency of a Taiwanese bank using data envelopment analysis with an undesirable factor," African Journal of Business Management, vol. 5, no. 8, pp. 3220-3228, April 2011.

[25] J. L. Hu, Y. Li, and Y. H. Chiu, "Ownership and nonperforming loans: evidence from Taiwan's banks," The Developing Economies, vol. 42, no. 3, pp. 405-420, 2004.

[26] H. Fukuyama and W. L. Weber, "Japanese banking inefficiency and shadow pricing," Mathematical and Computer Modelling, vol. 48, no. 11-12, pp. 1854-1867, 2008.

[27] Y. Li, "DEA efficiency measurement with undesirable outputs: An application to Taiwan's commercial banks," International Journal of Services, Technology and Management, vol. 6, no. 6, pp. 544-555, 2005.

[28] K. H. Park and W. L. Weber, "A note on efficiency and productivity growth in the Korean Banking Industry, 1992-2002," Journal of Banking and Finance, vol. 30, no. 8, pp. 2371-2386, 2006.

[29] Z. Geng and X. Zhai, "Effects of the Interest Rate and Reserve Requirement Ratio on Bank Risk in China: A Panel Smooth Transition Regression Approach," Discrete Dynamics in Nature and Society, vol. 2015, Article ID 571384, 2015.

[30] W. W. Cooper, S. Li, L. M. Seiford, K. Tone, R. M. Thrall, and J. Zhu, "Sensitivity and stability analysis in DEA: some recent developments," Journal of Productivity Analysis, vol. 15, no. 3, pp. 217-246, 2001.

[31] L. M. Seiford and J. Zhu, "Modeling undesirable factors in efficiency evaluation," European Journal of Operational Research, vol. 142, no. 1, pp. 16-20, 2002.

[32] P. L. Brocket and B. Golany, "Using rank statistics for determining programmatic efficiency differences in data envelopment analysis," Management Science, vol. 42, no. 3, pp. 466-472, 1996. 


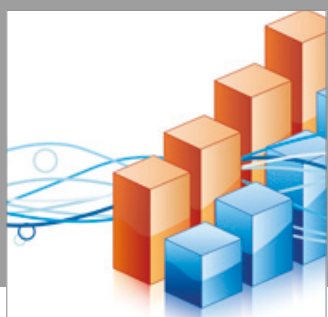

Advances in

Operations Research

vatersals

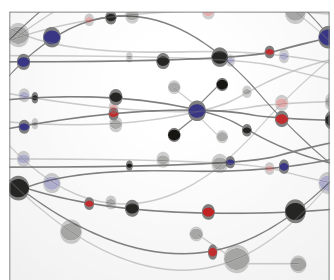

\section{The Scientific} World Journal
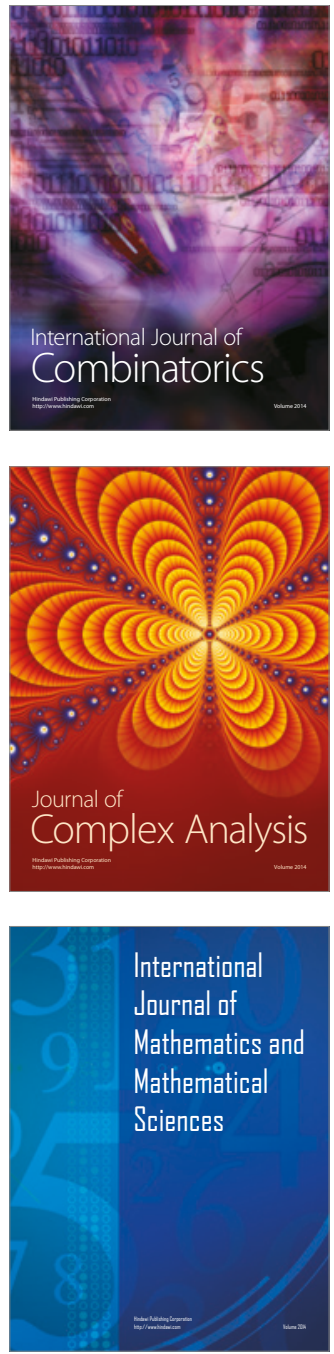
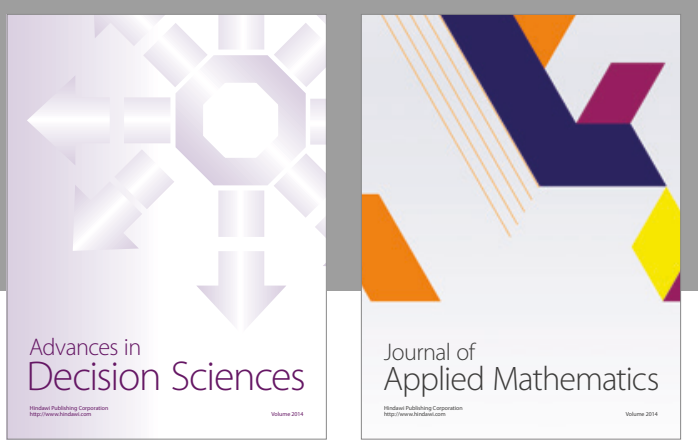

Algebra

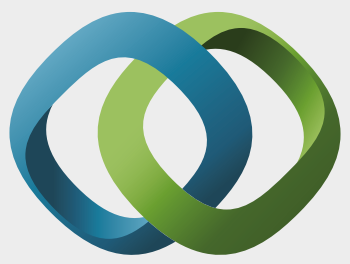

\section{Hindawi}

Submit your manuscripts at

https://www.hindawi.com
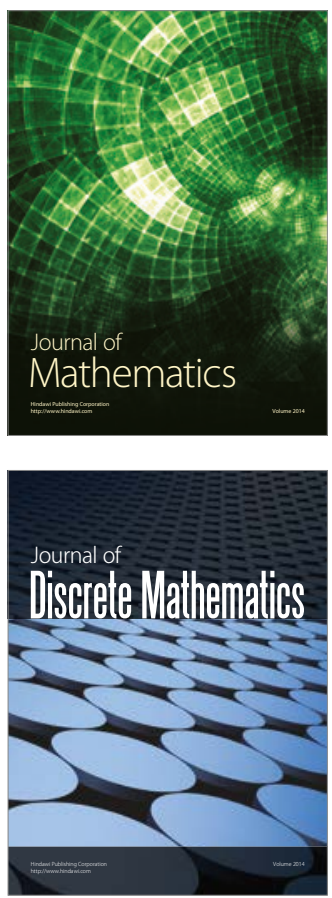

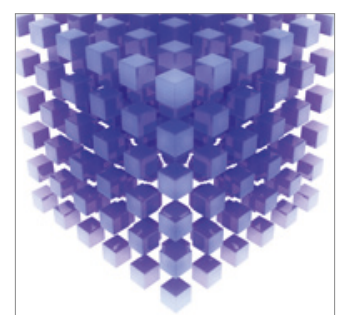

Mathematical Problems in Engineering
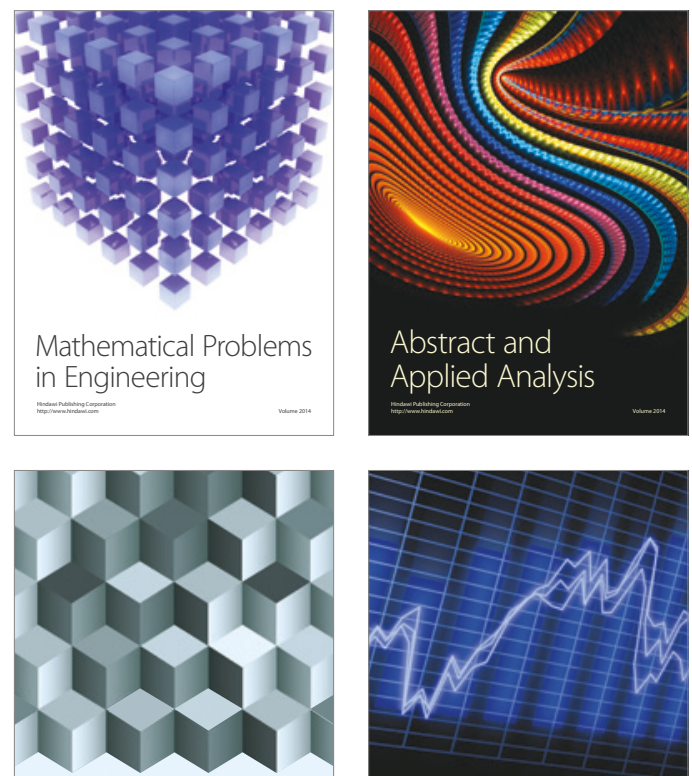

Journal of

Function Spaces

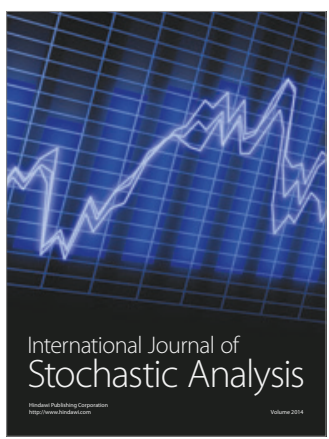

Probability and Statistics
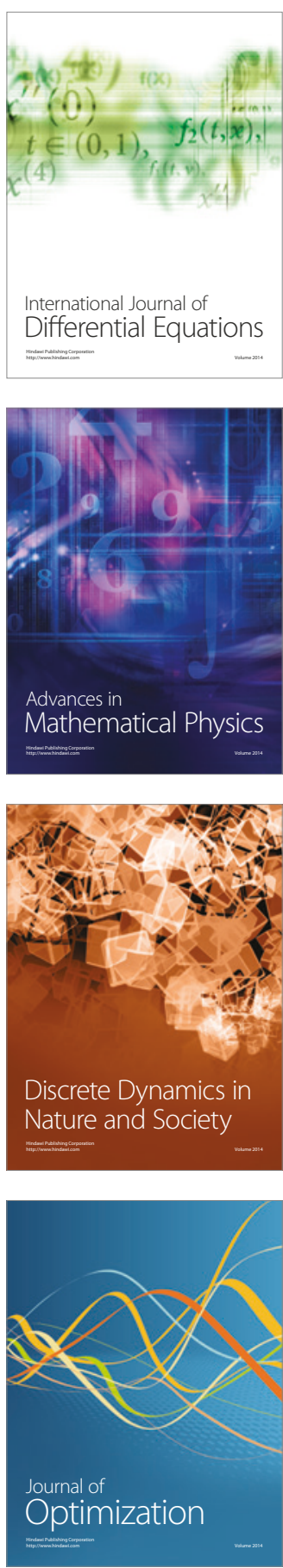